\title{
THE EFFECTIVENESS OF THE PEDAGOGICAL SYSTEM OF PREPARATION OF FUTURE TEACHERS-PHILOLOGISTS FOR RESEARCH ACTIVITY
}

\author{
Anna Zaika \\ Assistant Professor, National University of "Kyiv-Mohyla Academy", Ukraine \\ e-mail: annazaika050689@gmail.com, orcid.org/0000-0002-2565-6837
}

\section{Summary}

The article shows that the preparation of future philology teachers for research activity on the idea of a systematic activity approach to the development of personality is realized through a rational combination of effective educational technologies and natural human activity for self-realization. The developed pedagogical system provides the usage of a complex of pedagogical influences on formation of readiness of future philology teachers for realization of research activity and is carried out step by step, according to level of mastering by students of system of theoretical knowledge, practical skills and experience of research search and accordingly organized extracurricular and experimental research work in a higher educational institution.

In the course of research and experimental work we have fully confirmed the formulated hypothesis that the effectiveness of the formation of readiness for research work of future philology teachers in higher educational institutions can be achieved if this process is based on the development and implementation of a system that provides organizational and methodological provision of the gradual development of all components of readiness, the organization of scientific collaboration of students and teachers in order to self-improve the personality of the future philology teacher in professionally oriented research activities.

The results of experimental work confirmed the effectiveness of the developed system of readiness formation for research work of future philology teachers, which was introduced in the experimental group.

Keywords: readiness, criterion, component, indicator,

\section{DOI: https://doi.org/10.23856/3872}

\section{Introduction}

The development of modern civilization is characterized by innovative processes in all spheres of public life. The natural increase of requirements to the level and quality of education encourages the search for new ways to improve the educational process in school in order to help every young person to find themselves, choose their own way of life, self-realization. Teacher's education and professional competence includes the ability to navigate freely in the flow of scientific information, to understand new pedagogical technologies, to analyze alternative and variable curricula, to use progressive pedagogical experience. One of the important tasks of preparation of a philology teacher in school is the formation of his research skills as a necessary condition for the growth of his professional level, orientation in research and practical experience. In pedagogical theory, the problem of involving students in research work is studied from different points of view. Representatives of the professional and active approach (B. Gershunsky, Y. Lavrikov, S. Smirnova, L. Heister) interpret it as a model of future independent activity of a teacher.

The idea of the need to prepare students for research, creative and exploratory work is found in the works of S. Shatsky, V. Sukhomlinsky, V. Zagvyazinsky, V. Slastyonin and 
others. Conceptual principles of professional training of future teachers for creative activity are revealed in research of I. Zyazyun, M. Nikandrov, N. Nychkalo, M. Kukhareva. The need to prepare a philology teacher to conduct research with school students in future professional activities is confirmed by the requirements of the State educational standard of higher professional education. Among the general characteristics of the specialist's education are the skills of modern methods of searching, processing and using information, the ability to interpret and adapt it in their professional activities.

At the same time, despite the significant number of publications on this problem, the accumulated experience of pedagogical institutions, the established practice of the system of teacher training is not focused on the development of research potential of future philology teachers. Analysis of the state of preparation of future philology teachers to carry out research work with school students shows that higher education institutions do not sufficiently use their capabilities to form a future teacher as a leader of advanced scientific thought and organizer of scientific work in school.

\section{The structure of the pedagogical system}

One of the important areas of improving the work of higher pedagogical school in modern conditions is the urgent need to create such a pedagogical system that provides conditions for self-development of the individual, the maximum use of its potential. For the future philology teacher special purpose is acquired by purposefulness, sharpened feeling of new, desire for self-improvement and creative search, use of modern forms, methods, the latest scientific data and technologies of training. Therefore, the formation of future teachers of philology research skills is a necessary condition for them to achieve the appropriate professional level, orientation in a diverse range of innovative pedagogical technologies and research.

In our opinion, systematic, activity, personality-activity and personality-oriented approaches can become the methodological basis for creating a model of preparation of philology teacher for research work.

To identify the main elements of the educational process, we will make a structural analysis of the learning process as a pedagogical system.

Solving the problem of preparing future philology teachers for research will be successful in providing the following pedagogical conditions:

1) awareness of future philology teachers of the need to master research skills as a mandatory component of their professional training (Ananyev, 1980);

2) integration of the content of preparation for research work with the content of the disciplines of the psychological and pedagogical cycle and pedagogical practice (Khomych, 1988);

3) gradual inclusion of future philology teachers in research activities through various forms of classroom and extracurricular research work (Sherban, 1988);

4) effective pedagogical guidance of research work of future philology teachers at different stages of training (Kraevskij, 1983).

The implementation of certain conditions is carried out through the main components of the model of the process of preparation of future philology teachers for the implementation of research work, which are the target; stimulating and motivational; semantic; operational and active; control and regulatory; evaluative and effective.

The target component is one of the main components of training a future philology teacher. Any pedagogical process begins with the goal, regardless of its complexity and duration. The target component has the following functions: 
- it ensures teachers' awareness of the purpose of vocational training and its delivery to the subjects of training;

- it forms in them a positive attitude to professional activity in general and to a specific specialty, in particular;

- it forms in them a visual image of their educational and cognitive activities;

- it provides formation and development of semantic motives and motivation of educational-cognitive and professional activity.

Let us consider the stimulating and motivational component of the model of preparing students for research work.

The leading motives of pedagogical and research activity are personal motives, which are substantiated in the research of N. Kuzmina, V. Andreev, Z. Isaeva, L. Kondrashova, O. Yaroshenko.

Personal motives are interests in action. Interest is important in the implementation of any activity, including research. If a teacher is not interested in conducting some kind of research activity, then neither the demands of society nor the demands of the administration will be able to force him to engage in research activities.

The formation of the motivational basis of the readiness of future philology teachers for research work, in addition, is significantly influenced by the positive attitude of students to the teacher, his personal and professional qualities, and thus to the discipline, to his research (Yaroshenko, 1997).

The semantic component of the model of preparation of students of pedagogical college for research work contains everything that makes up the concept of "content of education", and which means a set of professional knowledge, skills and abilities that are part of the professional profile of a teacher of philology; system of general and practical skills, which is the basis of research activities; experience of creative activity and attitude to it.

The content of the operational component is the organization of practical educational and cognitive activities of students to master the educational material, the process of mastering the system of research skills necessary for their own research activities and the system of pedagogical skills that ensure teacher readiness to guide students' research, self-analysis and reflection

The control and regulatory component of the model of preparation of future philology teachers for research work is aimed at clarifying the effectiveness of the entire model, studying the effectiveness of each of its components, timely making optimal adjustments. A significant role should be played by students' self-control in the form of self-checking the depth of mastering the relevant theoretical knowledge, correctness and speed of tasks, evaluation of their own actions, optimal solutions. Control and self-control provide feedback in the learning process the teacher and student receive information about the effectiveness of the process and the results of research work of students. They can be considered as a diagnosis of the degree of readiness for the next educational, educational and research activities in the planned process of preparing students for various types of research work (Kondrashova, 1987).

\section{The analysis of the results of experimental work}

In the course of the formal stage of the experiment, 65 students were involved in the sample, who study at the educational qualification level of the Bachelor at the National University "Kyiv-Mohyla Academy". Since more senior students are engaged in research work, we involved 3-4 year students in the experiment. 
Starting the analysis of the effectiveness of a particular system, we must first emphasize that when analyzing the current state of readiness for research activities of future philology teachers, we had to find out the attitude of students to research. Taking all this into account, we propose to analyze the effectiveness of a certain system of formation of readiness for research work of future philology teachers in this direction.

Based on this, we formulated the criteria of readiness for research as follows: the first criterion - motivational, the second - cognitive, the third - technological.

According to traditional approaches to creating a criterion base, we have identified five levels of formation of certain indicators for each of the criteria: high, sufficient, medium, critical and low.

During the formative stage of research and experimental work, we tracked the dynamics of statistical data that reflect the progress of future philology teachers to a high level of readiness for research. The applied methods allowed to reflect on the development of readiness for research work in future philology teachers and to express this dynamic in the adaptation of students to the given criteria of formation of each of the levels of readiness of research work: motivational, cognitive, technological.

This dynamics allows us to identify the results of the impact of the developed system on the effectiveness of the formation of readiness for research work in future philology teachers. At this stage of the study, the final control of the effectiveness of the implementation of the system of step-by-step measures of system implementation and comparison of the obtained results with the observational stage of the experiment was carried out.

We turn to the analysis of the obtained empirical data on the motivational criterion: attitude to research as a personal value, the need for creative self-expression, interest in active participation in research, independence in choosing research tasks and forms of work; desire to participate in research competitions, speak at scientific conferences, seminars, persistence in overcoming difficulties in solving research problems

It can be noted that the level of development of the motivational criterion in the experimental group has significantly increased. The results of the study indicate that the level of attitudes to research as a personal value, the need for creative self-expression, the desire to learn, master more significantly exceeds that of the control group (respectively, high and sufficient experimental group $-18.5 \%$ and $32,4 \%$, the control group $-14.9 \%$ and $18.6 \%$ ).

However, such motivational orientations of scientific activity as activity in self-development, desire to learn, master more than the curricula offer, the need for creative self-expression have approximately the same indicators. Thus, in the motivational sphere of the student of the experimental group the current motives of research activity are more pronounced, there is an active position in relation to the professional orientation of research activity.

Investigating the level of readiness for research work in future philology teachers by cognitive criteria on indicators: understanding the role and importance of solving research problems in the professional activities of teachers; knowledge of the types of research tasks solved by teachers in their professional activities and the requirements for the results of their solution; knowledge of the requirements proposed for research projects, programs; knowledge of methods for solving research problems and the conditions of their application, we obtained the following results. Analysis of the formation of the cognitive criterion of readiness for research work of future teachers of philology revealed that students of the experimental group to a greater extent than students of the control group, are aware of the role of research in the educational process in higher education.

They have a fairly high level (sufficient) expressed knowledge of the types of research tasks and requirements for the results of their solution (control group $-12.3 \%$; experimental 
group $-19.8 \%$ ). The study showed that at the end of the experimental work in the experimental group there is an increase in the overall level of cognitive criterion of the research culture in relation to the control group (respectively high and sufficient experimental group $-12.5 \%$ and $21.4 \%$; control group $-8 \%$ and $13,6 \%$ ).

Analyzing the results by technological criteria, we note a positive trend in students of experimental groups. We see that the highest rate of formation in the experimental group have such skills as working with literary sources (compiling a bibliography, reviewing, annotating literature) - a high 23\%, sufficient - 34\%. Quite weakly similar skills are expressed in students of the control group (high $-14.1 \%$, sufficient $-19.2 \%$ ). The average indicators of formation in both control and experimental groups have the ability to set and solve research problems, select and apply adequate research methods (control group $-46.0 \%$ experimental group $-38.6 \%$ ), activity in presenting the results of their own and research work (control group $-39.6 \%$, experimental group $-61.0 \%$ ), as well as the ability and skills to carry out reflective activities, although in the experimental group these indicators are higher (control group $-37.4 \%$, experimental group $47.8 \%$ ). This fact indicates that these questions cause students difficulties in further study. However, the technological component of the research culture after purposeful training is quite clear.

\section{Conclusions}

Thus, according to the results of the formative stage of the experiment in the experimental group there were significant positive changes in the level characteristics of the formation of readiness for research work of future philology teachers. At the ascertaining stage of the experiment, a high level of readiness was not recorded in both groups. According to the results of the final cut in the experimental group, $16.2 \%$ of future specialists have already reached a high level, and in the control group the percentage of students of this level was $9.6 \%$, which is much less than in the experimental group. There is a positive dynamics of increasing the number of students in the experimental group, which are close to a high and sufficient level of readiness. The general conclusion of the analysis of data on the assessment of the formation of the readiness of research work of future philology teachers is the fact that the experimental groups clearly see the advantages, which consist of a greater personal orientation of training; understanding the role and importance of solving research problems; knowledge of the requirements proposed for research projects, programs; knowledge of methods for solving research problems and conditions of their application; activity in self-development, the desire to learn more than the curriculum offers; in a creative attitude to their profession, which in general contributes to the high dynamic growth of all components of readiness for research work of future philology teachers.

The study does not cover all aspects of the problem. The issues of providing conditions for the implementation of a cross-cutting line of scientific training of future philology teachers by means of all types of educational and cognitive work during all years of study are awaiting further study.

\section{References}

Ananyev B.G. (1980). O cheloveke kak subekte vospitaniya [About the person as a subject of education]. Moscow: Pedagogika. [in Russian]

Kondrashova L.V. (1987). Nravstvenno-psihologicheskaya gotovnost studenta $k$ uchitelskoj deyatelnosti [Moral and psychological readiness of the student for teaching]. Kiev: Visha shkola. [in Russian] 
Kraevskij V.V. (1983). Prepodavanie kak tvorcheskaya deyatelnost uchitelya [Teaching as a teacher's creative activity]. Moscow: Prosveshenie. [in Russian]

Khomych L.O. (1998). Profesiino-pedahohichna pidhotovka vchytelia pochatkovykh klasiv [Professional and pedagogical training of primary school teachers]. Kiev: Mahistr. [in Ukrainian] Sherban P.N. (1988). Aktivnye metody podgotovki budushih uchitelej [Active methods of preparing future teachers]. Kiev: Znannya. [in Russian]

Yaroshenko O.H. (1997). Hrupova navchalna diialnist shkoliariv: teoriia i metodyka [Group learning activities of students: theory and methodology.]. Kiev: Partner. [in Ukrainian] 